\title{
THE INTENSITY OF COMPETITIVE INTERACTIONS BETWEEN SPRING WHEAT (TRITICUM AESTIVUM L. EMEND. FIORI ET. PAOL) AND SPRING BARLEY (HORDEUM VULGARE L.) UNDER DIFFERENT FERTILISATION CONDITIONS
}

\author{
Kinga Treder, Maria Wanic, Janusz Nowicki \\ Department of Agriculture Systems, University of Warmia and Mazury in Olsztyn, 10-718 Olsztyn, Pl. Łódzki 3, Poland \\ e-mail: mwanic@uwm.edu.pl
}

Received: 10.03 .2008

$\mathrm{S} \mathrm{u} \mathrm{m} \mathrm{m} \mathrm{a} \mathrm{r} \mathrm{y}$

Competitive interactions between spring wheat and spring barley were traced based on a pot experiment. In the years 2003-2004, three cycles of the experiment were carried out in a greenhouse. Two spring cereals - wheat and barley, sown in a mixture and in a monoculture, with different mineral fertilisation levels, were the object of evaluation and comparison. The experiment was set up according to the additive scheme, determining dry weight values for both species in 5 growth stages (emergence, tillering, shooting, heading and ripening). Results were used to determine relative yields and competition ratios. It was demonstrated that competition between the cereals started already from the emergence stage and lasted till the end of vegetation, manifesting itself with the greatest strength at the heading stage, but thereafter it weakened in the NPK poorer environment. Access to a larger pool of macroelements resulted in the intensification of competitive interactions. Spring barley used the limited growth factors better than wheat from shooting till the ripening period, and a reverse relation was exhibited only at the tillering stage.

Key words: competition, spring wheat, spring barley, phenophases, fertilisation, canopy growth rate, competition ratios

\section{INTRODUCTION}

Plants growing together, both within the same population and in different populations, exert different effects on one another. Sometimes, they are small, but sometimes they are very large. Competition is included among more important negative effects ( C o n n o $11 \mathrm{y}$ et al. 2001). Its pattern and intensity significantly affect the dynamics of biocenoses - their number, composition and structure. This process also modifies the biological rhythm of individuals, their morphological traits and fertility (Keddy, 1989; Sattore and
Snaydon, 1992; Semere and Froud-Willi a m s, 2001; S o b k ow ic z, 2003). At different stages of joint vegetation of plants, competition occurs with variable intensity. Generally, it starts already in early phenophases and lasts throughout the whole growing period, at the last stage sometimes turning into the complementary use of resources, that is, a positive phenomenon (Fukai and Trenbath, 1993; S o b k ow ic z, 2003).

Even though literature on competition is relatively wide, nevertheless, most of it is limited either to the initial stage of growth and development or to the final stage. There are few studies which trace this process throughout the whole growing period ( $\mathrm{S}$ o b $\mathrm{k} \mathrm{ow}$ i c z , 2003), and moreover there is a large divergence of results obtained, which is mostly attributable to the use of different research methods (C o n n o lly et al. 2001).

The aim of the study was to evaluate the effect of competition occurring between spring wheat and spring barley on the intensity of this process in particular periods of joint vegetation, as compared to monoculture cultivation.

\section{MATERIALS AND METHODS}

Three cycles of a pot experiment, carried out in the years 2003-2004 in a greenhouse of the Faculty of Biology of the University of Warmia and Mazury in Olsztyn, formed the basis for the study. The object of the study was two spring cereals: wheat (cv. Torka) and barley (Rabel), sown in a two-component mixture and in a monoculture. The first cycle of the experiment lasted from 10 April 2003 to 7 July 2003, the second one covered the period from 26 February 2004 to 25 May 2004, and the third one from 18 September 2004 to 20 December 2004. The experiment was conducted 
according to the additive scheme the essence of which is that the number of plants of each species in a mixture is the same as in the pure stand. It allows interspecific competition to be investigated without distorting the picture by intraspecific competition and enables this process to be traced right from the beginning of plant vegetation (Ke ddy, 1989; S e mere and FroudWilli a m s, 2001; S obkowi c z, 2001).

The following factors were evaluated:

1. NPK mineral fertilisation levels:

- standard dose: $\mathrm{N}-0.50, \mathrm{P}-0.20, \mathrm{~K}-0.45 \mathrm{~g}$ per pot, which, under field conditions, amounted to a total of $162{\mathrm{~kg} \times h \mathrm{a}^{-1}}$ of pure component, including: $\mathrm{N}-70$, $\mathrm{P}-26, \mathrm{~K}-66$

- $50 \%$ increased dose: $\mathrm{N}-0.75, \mathrm{P}-0.30, \mathrm{~K}-0.675$ in $\mathrm{g} /$ per pot; (a total of $243 \mathrm{kgxha}^{-1}$; including: $\mathrm{N}-105$, $\mathrm{P}-39, \mathrm{~K}-99)$.

2. plant sowing methods:

- in a mixture

- in a monoculture.

In the paper, the standard dose will be termed as $1 \mathrm{NPK}$, and the increased dose - 1.5 NPK.

The substrate in the experiment was medium, typical brown soil, formed from light loamy silty sand, on loose silty sand. It was characterised by the organic substance content ranging between 1.22 and $1.91 \%$, a slightly acid reaction $(\mathrm{pH}$ of 5.9-6.3 in $1 \mathrm{M} \mathrm{KCl}$ ) and high abundance of available forms ( $\mathrm{g} \times \mathrm{kg}^{-1}$ of soil) of the following: phosphorus (117-136), potassium (83-123) and magnesium (14-17). Kick - Brauckmann pots with a diameter of $22 \mathrm{~cm}$ and a depth of $28 \mathrm{~cm}$ were used for the experiment. Before filling the pots with soil (in an amount of $8 \mathrm{~kg} \times$ pot), it was sieved and then carefully mixed with appropriate doses of mineral fertilisers in the form of urea, potassium phosphate and potassium sulphate. Nitrogen was applied twice during the growing period: the first part was introduced into the soil before sowing (together with phosphorus and potassium), and the second one at the beginning of the barley shooting stage.

During the vegetation, water losses in the pots were replenished every day up to $50 \%$ of maximum water capacity of the soil. In the greenhouse, a temperature of $20-22^{\circ} \mathrm{C}$ was maintained, except for the period of vernalisation when it was lowered to $6-9^{\circ} \mathrm{C}$. In the second and third cycles, due to the fact that they were carried out in conditions other than in reality, additional artificial lighting was applied; its duration was adapted to the needs of both species.

Based on plant dry weight values determined in 5 cereal growth stages, i.e. in the period of emergence (according to Zadoks $10-13$ ), tillering (25), shooting (37), heading (55) and ripening (87 - 91), calculations were made of relative yields (RY), relative yield total (RYT) and competition ratios (CR), using the follow- ing formulas (S e mere and Froud-Willi a ms, 2001; S o b k o w i c z, 2001, 2003):

relative yields: $\quad \mathrm{RY} i=\mathrm{Y} i j / \mathrm{Y} i i \quad \mathrm{RY} j=\mathrm{Y} j i / \mathrm{Y} j j$

relative yield total: $\mathrm{RYT}=\mathrm{RY} i+\mathrm{RY} j$

competition ratio: $\mathrm{CR} i j=\mathrm{RY} i / \mathrm{RY} j \mathrm{CR} j i=R Y j / \mathrm{RY} i$

where:

$\mathrm{RY} i$ - relative yield of species $i$ (spring wheat)

$\mathrm{RY} j$ - relative yield of species $j$ (spring barley)

Yii - yield of species $i$ (spring wheat) in the pure stand

Yjj - yield of species $j$ (spring barley) in the pure stand

Yij - yield of species $i$ (spring wheat) in the mixture with species $j$ (spring barley)

Yji - yield of species $j$ (spring barley) in the mixture with species $i$ (spring wheat)

RYT - relative yield total

CRij - competition ratio of spring wheat relative to spring barley

CRji - competition ratio of spring barley relative to spring wheat

If there are no competitive interactions between the species in a mixture, the yield of each of them is the same as in a pure stand $(\mathrm{RY}=1.0 ; \mathrm{RYT}=2.0)$. RYT values ranging between 1.0 and 2.0 mean that the competition relates only to a part of environmental resources, and the remaining part is used by plants in a complementary way.

The competition ratio (CR) of species $i$ (wheat in this case) relative to species $j$ (barley) means a proportional change in the mixture composition compared to the expected composition, that is, a composition in which the shares of both species in the yield are the same as in total biomass produced by the combination of pure crops (objects without competition).

Numerical data are presented in the form of mean values from the three cycles of the study. The results relating to plant dry weight were processed statistically with the analysis of variance, using the Tukey's test. Relative yields (RY) and the relative yield total are presented in a figure in the form of two-dimensional diagrams (S a t tore and Snaydon, 1992).

\section{RESULTS}

The cultivation of spring wheat with spring barley did not differentiate their biomass in the period of emergence (Fig. 1). However, already at the tillering stage, its significant reduction was found in both species. In wheat, as the growth progressed, the difference in dry weight yields between the mixed sowing and the pure stand successively deepened until the heading stage, and thereafter, at the end of vegetation, it slightly decreased. This cereal showed a stronger response 


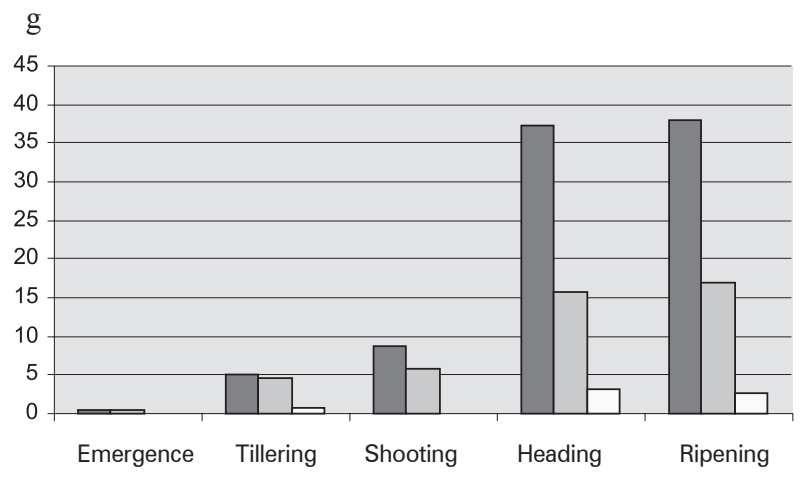

1 NPK

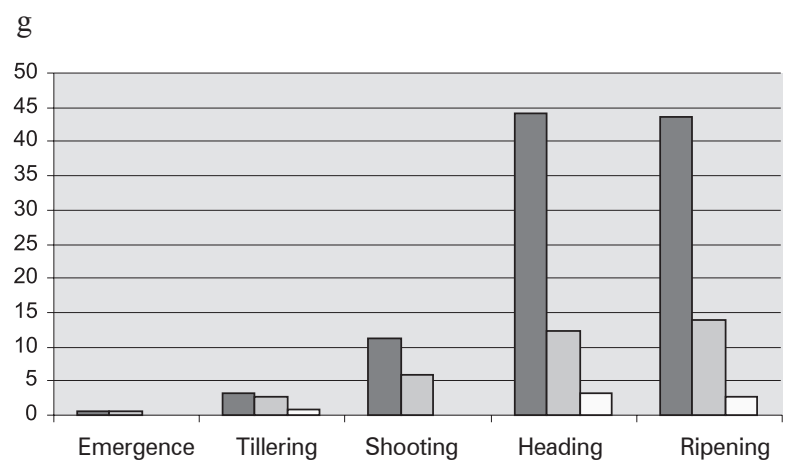

\section{Wheat}

1.5 NPK

pure stand; $\square$ mixed stand; $\square$ NIR ${ }_{(\mathrm{p}=0.05)}$ (significat differences for sowing method)

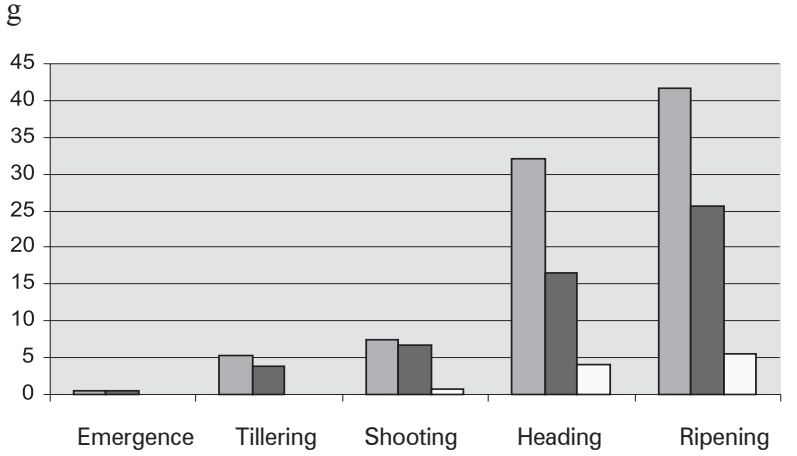

1 NPK

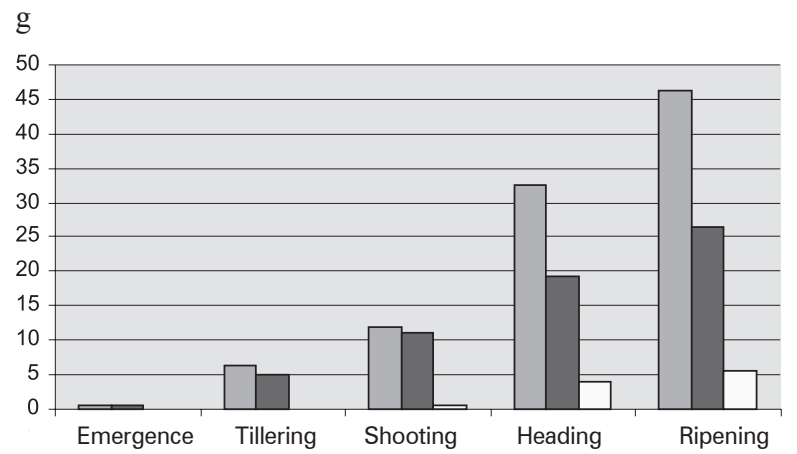

Barley

pure stand; $\square$ mixed stand; $\square$ NIR $_{(\mathrm{p}=0.05)}$ (significat differences for sowing method)

Fig. 1. Dry weight of aboveground parts of cereals (g/pot) at particular growth stages. 


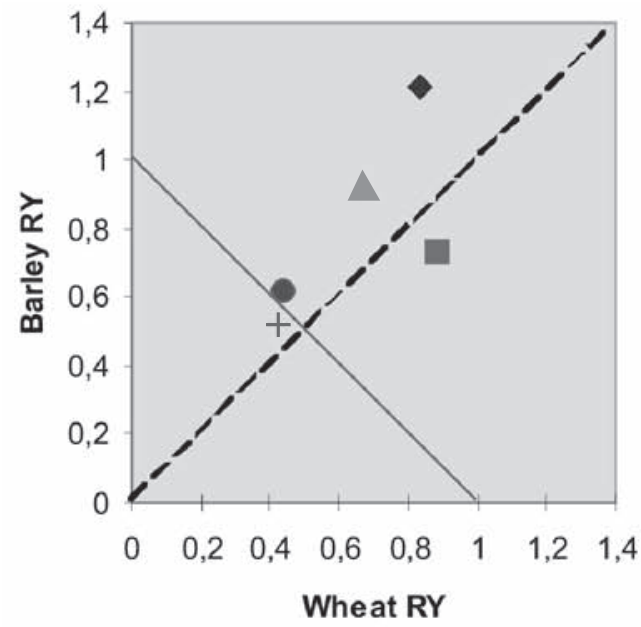

a

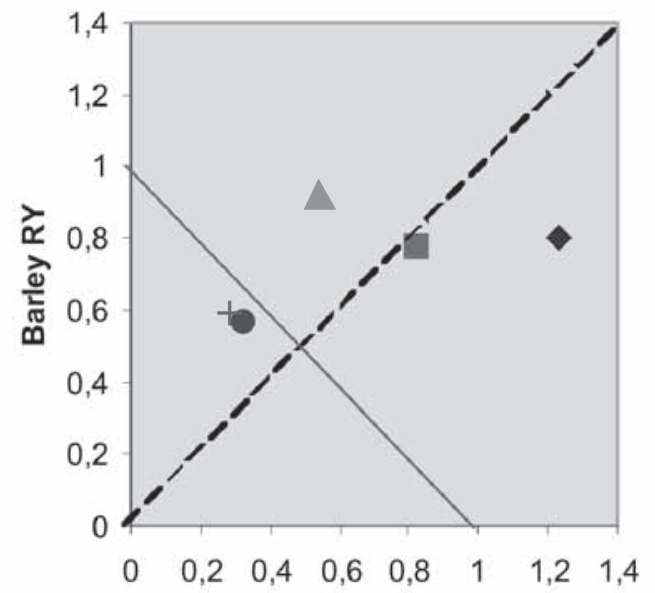

b

Wheat RY

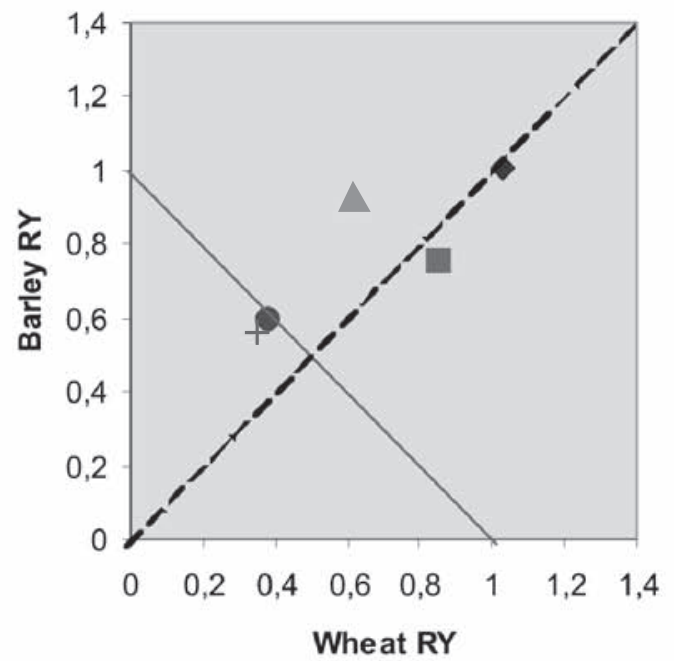

emergence

tillering

C

shooting

+ heading

ripening

Fig. 2. Wheat and barley relative yields (RY) at particular growth stages: $\mathrm{a}-1 \mathrm{NPK}, \mathrm{b}-1.5 \mathrm{NPK}, \mathrm{c}-$ the mean for doses, (points in the diagram mean relative yield total (RYT) values, solid line RYT $=1$, interrupted line - no competition). 
to the presence of barley in the environment richer in microelements. In barley in the mixed stand, the greatest decrease in biomass was noted at the heading and ripening stages (its reduction was greater than in the case of wheat). At the tillering and ripening stages, larger differences between the sowing methods were noted in the object poorer in microelements, whereas at the other stages of joint vegetation, NPK doses had no effect on their values.

The information shown in Fig. 2 shows that competitive interactions between the cereals occurred already at the emergence stage, as proved by the values of relative yields - RY. In the mixed stand with the NPK standard dose, wheat produced a smaller aboveground weight than in the single-species stand $(\mathrm{RY}=0.83)$. At the same time, this cereal stimulated the growth of barley, what was reflected in its weight which turned out to be higher than in the pure stand $(\mathrm{RY}=1.21)$. A different pattern developed in the object richer in NPK, since the aboveground dry weight of barley in the mixture was smaller here than in the monoculture $(\mathrm{RY}=0.80)$. But wheat responded positively to the presence of barley, what resulted in its production of a larger biomass than in the pure stand $(\mathrm{RY}=1.23)$. A positive effect of wheat on barley in the object poorer in NPK, and of barley on wheat - in the NPK richer object, is difficult to explain. Perhaps it resulted from allelopathic interactions, however, given that the relations between RY values in both fertilisation treatments were patterned differently and the content of allelocompounds was not examined, this condition cannot be discussed explicitly. In both fertilisation treatments, the relative yield total (RYT) of the mixture in the period concerned exceeded the value of 2 , that is, it surpassed the aggregate yield of both species in the pure stand.

From the tillering stage, resources ceased to be sufficient for both species, what deepened the competition process. Initially, in both fertilisation treatments, it occurred with a similar intensity $(\mathrm{RYT}=1.61$ and $1.60)$. At this time, the cereals competed for $39 \%$ of resources and used $61 \%$ in a complementary way. Wheat turned out to be slightly more effective in obtaining resources, particularly in the object poorer in dietary minerals $(\mathrm{RY}=1 \mathrm{NPK}-0.88 ; 1.5 \mathrm{NPK}-0.82)$. The process of competitive interactions between the mixture partners increased with the passage of time. At the ripening stage, the strength of mutual effects slightly weakened, but only in the object poorer in macroelements. In the object richer in NPK, the rivalry between the cereals from the shooting stage until the end of vegetation related to a larger pool of resources than in the poorer object (hence, it was more severe). Thus, at the shooting stage, on the average basis for the fertilisation treatments, the plants in the mixture competed for $47 \%$ of resources and shared the remaining pool (53\%) between them. During the shooting stage, the dominance of barley over wheat was clearly evident. In the mixed stand, its yield was lower by only $8 \%$ compared to the pure stand, whereas in the case of wheat it accounted for bare 67 and 54\% of its efficiency in the monoculture. This correlation indicates a partially compensatory nature of competition in this period. At the heading stage, full competition occurred between the mixture components for the limited growth factors. The relative yield total reached here a smaller value than $1(\mathrm{RYT}=0.94-$ in the object with $1 \mathrm{NPK} ; 0.87-1.5$ NPK). Barley proved to be more efficient in obtaining resources (which were over 50\% smaller compared to the joint requirements of both plants). Its dominance over wheat manifested itself particularly clearly in the object with increased mineral fertilisation. Thus, it used significantly more growth factors, which were deeply deficient in this period. In the last period of joint vegetation, compared to the heading stage, the competition between the cereals was on the same level in the object supplied with the standard dose, and it slightly grew in the object with the increased dose. At this time, the plants competed for $94 \%$ of resources in the environment poorer in dietary minerals, and only $6 \%$ were obtained in a complementary way. Similarly to the previous period, barley again proved to be more efficient in their use (in particular, in the richer environment).

An analysis of the RYT values obtained in the experiment clearly shows that the cereals grown under the conditions of the increased mineral fertilisation level competed more strongly than the plants growing in the environment with the standard content of nutrients in the substrate. The process of competition between the cereals started at the emergence stage and lasted throughout the whole growing period, manifesting itself with the greatest strength during heading.

In the experiment conducted, the strength of competitive interactions between the cereals changed during their vegetation, and the mineral fertilisation levels had a great effect on the intensification of this process (Fig. 3). Although the mean values for the fertilisation treatments may suggest a similar intensity of the cereals' mutual effects on each other at the emergence stage, but due to the fact that in this period there was an excess of resources compared to the needs of the plants, the species did not compete for them, but they absorbed them relatively evenly (with a slight dominance of wheat). During tillering, the competitive strength of wheat relative to barley turned out to be slightly greater than that of barley relative to wheat, as evidenced by the CR values (1.12 and 0.89 ). However, already from the next period (shooting), barley started its dominance over wheat which lasted until the end of 

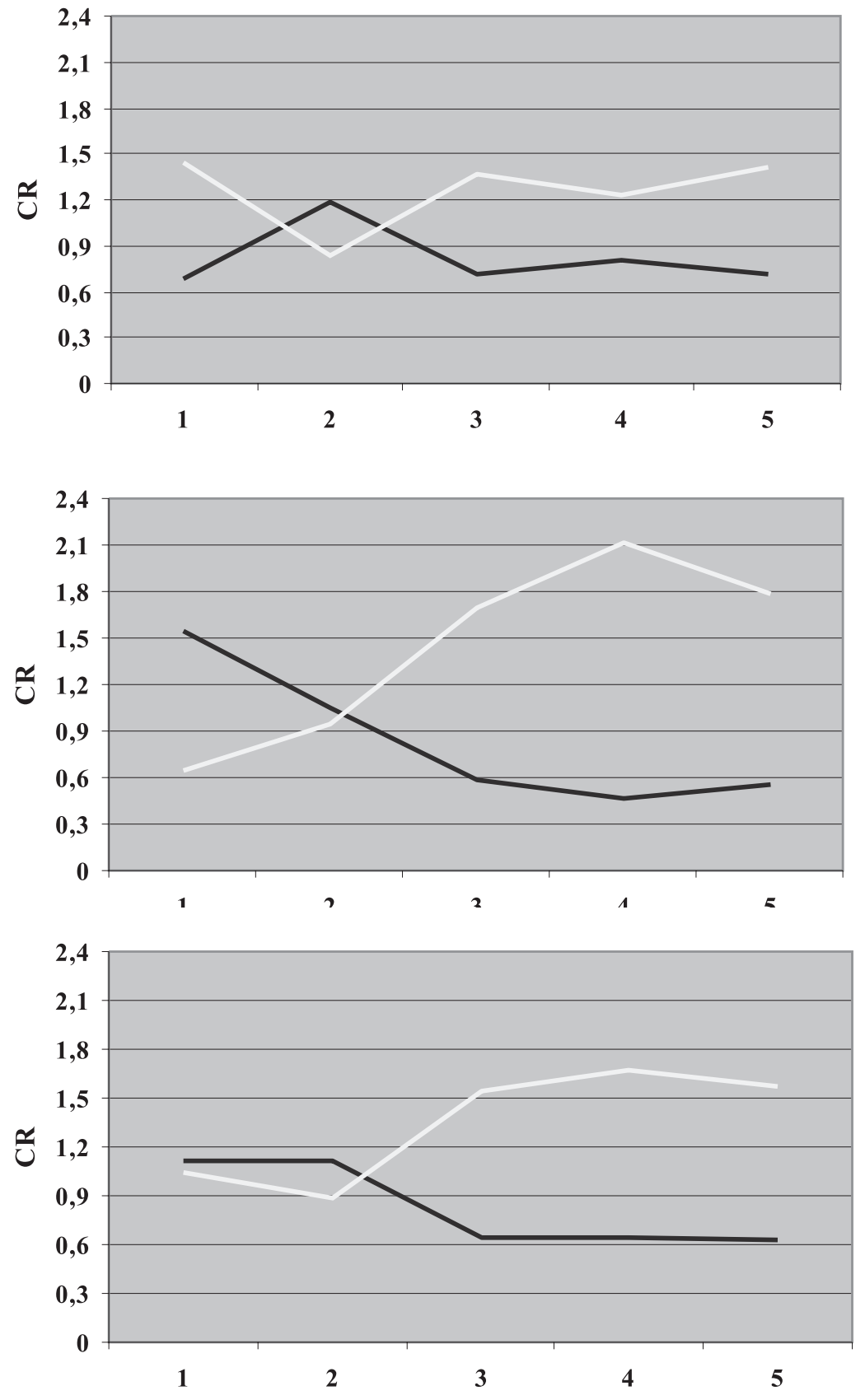

c

$$
\text { wheat - barley, — barley - wheat }
$$

1 - emergence, 2 - tillering, 3 - shooting, 4 - heading, 5 - ripening

Fig. 3. Competition ratios at particular growth stages at different fertilisation levels $(a-1$ NPK, $b-1.5$ NPK) and as the mean for doses (c). 
vegetation, being most evident at the heading stage (the $\mathrm{CR}$ value here was the highest in the whole life cycle of the plants and it was 1.67). But during the heading period, the wheat plants had the smallest impact on the partner, as confirmed by the lowest competition ratio for this species which reached a value of 0.65 . At the last growing stage, the effect of barley on wheat weakened. The above outlined relations between the cereals were modified under the influence of the abundance of macroelements in the substrate. In the object with the lower mineral fertilisation level, barley proved to be less competitive than wheat only at the tillering stage when the CR value for this cereal was lower than that for wheat and reached the lowest value in the whole period -0.84 . In the other periods, this cereal dominated over wheat; the strength of its effect was the greatest during the time of intensive stem elongation $(\mathrm{CR}=1.37)$, and in the subsequent periods of joint vegetation, it gradually decreased. On the other hand, wheat slightly "surpassed" barley only in the tillering period when the evaluated ratio reached the maximum value for this cereal - 1.18. Starting from the shooting stage, wheat - contrary to barley - reinforced its "strength" with the passage of time, as indicated by the gradually increasing CR values (but they were always less than one). In the substrate richer in NPK, during the emergence period, wheat used resources more effectively than barley, and during tillering, mutual effects equalised. However, already at the shooting stage, the competitive potential of barley increased $(\mathrm{CR}=1.70)$, and in the next period it reached the maximum value (the highest in the whole experiment) - 2.11. At this time, wheat was characterised by the weakest, in its whole life cycle, competitive ability; it was almost twice lower than in the object poorer in dietary minerals $(C R=0.47)$. At the final stage of joint vegetation, the intensity of competitive effects of barley weakened, whereas the strength of wheat increased.

\section{DISCUSSION}

In the experiment in question, the relative yield total $(\mathrm{RYT}=2.04)$ determined for both fertilisation levels at the emergence stage indicates the yield-forming effect of the mixture in this period. However, in the mixed stand in the environment poorer in NPK, a part of the growth factors proved to be less assimilable for wheat, whereas barley obtained them in accordance with its requirements. A reverse situation, however, was noted in the richer environment. The RY ratio value higher than 1 for barley in the first object, and for wheat - in the second one, may be an evidence of other (uncontrolled) factors which led to an increase in yield of both cereals. S o b k o w i c z (2001) claims that, at the initial stage of growth and development, the use of available resources and RYT values may not prove that competing species assimilate them more effectively than in a monoculture. According to the cited author, S e mere and Froud-Wili a m s (2001) as well as Vanderme e r (1989), in the early growing periods, competition between plant roots has a greater significance. Given the above, barley, as a species with a high growth rate and a larger number of radicles than wheat, potentially has better possibilities to obtain dietary minerals and accumulate biomass. Also, mutual interactions of cereals by means of biologically active substances released into the environment should not be excluded, as noted by J askulski and Rudnicki (1994). In our study, at the tillering stage environmental resources ceased to be sufficient for both species. In this period, the cereals rivalled for almost $40 \%$ of environmental resources which were obtained more effectively by wheat. During the shooting stage, the rivalry between the mixture components became more intense. Then, a marked dominance of barley became also evident and it maintained until the end of vegetation. The strongest competitive interactions were found at the heading stage and thereafter they weakened, but only in the objects with the basic fertilization dose. The results of our study do not fully correspond with the results obtained by S o b k o w i c z (2003) who observed the dominance of barley in two- and three-component mixtures with oat and triticale in all the periods analysed. A similar response of this cereal to mixed sowing with other cereal species was observed, among others, by Idziak and Michalski (2007), Jokinen (1991), M i chalski and Wali góra (1993), Rudnicki (1994), Rudnicki and Wasilewski (1993) as well as Taylor (1978). This condition could result from asymmetric competition defined by Schwinning (1996), which would mean that plants of the dominant species, which gained an advantage at the beginning of vegetation, used an unproportionally larger amount of resources than it appeared from their size. A consequence of this process was the increased dominance of the species during the subsequent growth stages and its negative impact on the other components (C o n nolly and Wa y ne, 1996). This type of effect is, according to Schwinning (1996), closely associated with competition for light.

The increased level of mineral fertilisation intensified the rivalry between the cereals, which coincides with the data presented by Jokine n (1991) and $\mathrm{L} \mathrm{a} \mathrm{mb}$ et al. (2006). S a t tore and S naydon (1992) obtained a different result in their experiment where RYT determined for cereals and Avena fatua, in full competition, was not differentiated by the applied nitrogen fertilisation doses (50 and $\left.100 \mathrm{~kg} \times h a^{-1}\right)$.

In the experiment conducted, at the initial stage of joint vegetation of the cereals, wheat proved to be 
a slightly stronger competitor, in particular in the objects richer in macroelements. This situation changed at the shooting stage when barley started its strong dominance over wheat; however, the intensity of competitive effects of this species was higher in the objects with the increased fertilisation level. This correlation was maintained until the end of vegetation, however, the strength of effects of this species weakened with the passage of time, whereas the competitiveness of wheat gradually increased, but still it did not match that of barley. It is consistent with the results of $\mathrm{J} \mathrm{o} \mathrm{k} \mathrm{-}$ in en (1991) who demonstrated that, along with the increase in the nitrogen fertilisation level, the share of barley grains in the mixture yield increased. It could be associated with a faster rate of growth and development as well as a shorter growing period of barley which, ripening earlier, limited its absorption of environmental resources and rivalry for light in favour of wheat. In this period, the so-called ontogenetic drift, described by Pietkiewicz (1985), could have taken place; it consists in increasing the share of nonassimilatory tissues in plant biomass of the species being at a more advanced development stage. Thus, it could have an effect on the decrease of the strength of competitive interactions. A similar response of barley sown together with oat and triticale at the final period of vegetation was noted by S obkowicz (2003). In the study, it was demonstrated that the competitive strength of wheat was weaker than that of barley. It is consistent with the results presented by $\mathrm{R} \mathrm{u} \mathrm{d} \mathrm{n} \mathrm{i} \mathrm{c} \mathrm{ki}$ and Wasilewski (1993) who, based on the calculated $\mathrm{R}$ ratio ( $\mathrm{RY}$ modification), found that wheat poorly tolerated the presence of barley in the canopy. In the authors' opinion, the above results may prove both a strong competitive effect of barley on wheat and its impact on the cereal in question by means of allelopathic growth inhibitors, as noted by L e s z c z y ń s k a and Grabińs ki (2004).

\section{REFERENCES}

Connolly J., Wayne P. 1996. Asymmetric competition between plants, Oecologia, 108: 311-320.

Connolly J., Wayne P., Bazzaz F. A. 2001. Interspecific competition in plants: how well do current methods answer fundamental questions? Am. Nat. 157 (2): 107-125.

Fukai S., Trenbath B. R. 1993. Processes determining intercrop productivity and yields of component crop. Field Crop Res. 34: 247 - 271.

Idziak R., Michalski T. 2007. Response of spring barley and oat plants to growing in the mixtures. ZPPNR, 516: 45-53.

Jaskulski D., Rudnicki F. 1994. Mutual effect between species of cereals in the course of germination. Frag. Agron. 1 (41): 89-94.
Jokinen K. 1991. Competition and yield performance in mixtures of oats and barley - nitrogen fertilization, density and proportion of the components. J. Agric. Sci. Fin. 63: 321-340.

Keddy P. A. 1989. Competition. Population and community biology series. Chapman and Hall, London.

Lamb E. G., Shore B. H., Cahill J.F. 2006. Water and nitrogen addition differentially impact plant competition in a native rough fescue grassland. Plant Ecol. DOI 10.1997/ s11258-006-9222-4. Springer.

Leszczyńska D., Grabiński J. 2004. Cereals germination in mixture stand - allelopathic aspect. Ann. UMCS, sect. E, 59 (4): 1977-1984.

Michalski T., Waligóra H. 1993. Estimation of productivity of spring barley and oats mixtures depending on the choice of cultivars. Rocz. AR w Poznaniu, Rol. 41: 47-55.

Pietkiewicz S. 1985. Tracer analisis of growth. Wiad. Bot. 29 (1): 29-42.

Rudnicki F., Wasilewski P. 1993. Badania nad uprawa jarych mieszanek zbożowych. Część II. Reakcja jęczmienia, owsa i pszenicy na uprawę w mieszankach. / Studies on the cultivation of spring cereal mixtures. Part II. A response of barley, oat and wheat to mixed cultivation. Roczniki AR w Poznaniu, CCXLIII: 66-71.

Satorre E. H., Snaydon R. W. 1992. A comparison of root and shoot competition between spring cereals and Avena fatua. Weed Res. 32: 45-55.

Schwinning S. 1996. Decomposition analysis of competitive symmetry and size structure dynamics. Ann. Bot. 77: 47-57.

Semere T., Froud-Williams R. J. 2001. The effect of pea cultivar and water stress on root and shoot competition between vegetative plants of maize and pea. J. Appl. Ecol. 38: 137-145.

Sobkowicz P. 2001. Aboveground and belowground competition between barley and oats in mixture during early stage of growth. Fragm. Agron. 2 (70): 103-119.

Sobkowicz P. 2003. Interspecific competition in mixtures of spring cereals. Zesz. Nauk. AR Wrocław: 458, Rozprawy CXCIV: 5-105.

Taylor B. R. 1978. Studies on a barley - oats mixture. J. Agric. Sci. Camb. 91 (3): 587-592.

Vandermeer J., 1989. The ecology of intercropping. Cambridge University Press., Cambridge: 1-256.

\section{Intensywność oddziaływań konkurencyjnych między pszenicą jarą \\ (Triticum aestivum L. Emend. Fiori et. Paol) \\ a jęczmieniem jarym (Hordeum vulgare $\mathrm{L}$.) w warunkach zróżnicowanego nawożenia}

\section{Streszczenie}

W oparciu o eksperyment wazonowy śledzono oddziaływania konkurencyjne między pszenicą jarą i jęczmieniem jarym. W latach 2003-2004 przeprowa- 
dzono w szklarni trzy cykle doświadczenia. Przedmiotem oceny i porównań były dwa zboża jare - pszenica i jęczmień, wysiane w mieszance i siewie jednogatunkowym przy zróżnicowanych poziomach nawożenia mineralnego. Eksperyment założono wg schematu addytywnego (dodawalnego), oznaczając w 5. fazach rozwojowych (wschody, krzewienie, strzelanie w źdźbło, kłoszenie i dojrzewanie) wielkość suchej masy obydwu gatunków. Wyniki posłużyły do określenia plonów względnych oraz współczynników konkurencji. Wyka- zano, iż rywalizacja pomiędzy zbożami rozpoczęła się już od fazy wschodów i trwała do końca wegetacji, objawiając się z największą siłą w fazie kłoszenia, po czym w środowisku uboższym w NPK uległa osłabieniu. Dostęp do większej puli makroelementów powodował nasilenie oddziaływań konkurencyjnych. Jęczmień jary lepiej niż pszenica wykorzystywał limitowane czynniki wzrostu od strzelania w źdźbło do okresu dojrzewania, a odwrotna relacja zarysowała się jedynie w fazie krzewienia. 